\title{
Master's and PhD Research Undertaken by Māori Psychotherapy University Graduates
}

\author{
John O’Connor and Verity Armstrong
}

PSYCHOTHERAPISTS, AUCKLAND

\section{Whakarāpopotonga}

Mai i ngā tekau tau e rua kua pahure ake nei, he whānui ngā paetahi Māori kaiwhakaora hinengaro (he rahi he huānga ki Waka Oranga) kua tahuri ki te whai i te tohu paerua me te rangahau whakapae Tākutatanga. Nō mātau te māringanui ki te whakatakoto atu i raro iho nei i te hua o ngā ingoa, ngā kaituhi me ngā whakarāpopotonga o te maha o ènei whāinga rangahau. E whakaatahia ana te maha me te hōhonu o te rapu haere a ngā pia Māori nei i te whakaoranga hinengaro a te kaimahi tangata whenua whakaora hinengaro me te kairangahau holi.

\section{Abstract}

Over the past two decades, a range of Māori psychotherapy graduates (many of whom are members of Waka Oranga) have undertaken Master's degree dissertation research and $\mathrm{PhD}$ thesis research. It is with pleasure that we outline below the titles, authors, and abstracts of many of these research undertakings. They reflect the diversity and depth with which Māori graduates have grappled with psychotherapy as indigenous practitioners and researchers.

\section{Introduction}

Māori graduates of AUT University and Te Wananga o Aotearoa have completed a wide range of research projects as part of their Masters' Degree dissertations, and $\mathrm{PhD}$ theses undertakings, exploring different aspects of psychotherapy theory and practice, as indigenous researchers and psychotherapeutic practitioners. Below you will find the titles, authors, supervisors, and abstracts, providing an overview of many of these research undertakings. Specifically, this research summary provides an overview of research that has been undertaken with a kaupapa Māori focus. It contributes to the development of Te Ao Māori perspectives in relation to psychotherapy, arising out of this focus. In addition, where the thesis or dissertation is available online, you will find a link at the end of the abstract, which you can search, to find the written research project in its entirety. We hope you will find this an engaging and helpful resource.

\footnotetext{
O’Connor, J., \& Armstrong, V. (2019). Master's and PhD research undertaken by Māori psychotherapy university graduates. Ata: Journal of Psychotherapy Aotearoa New Zealand, 23(1), 123-130. https://doi. org/10.9791/ajpanz.2019.11
} 


\title{
Towards a Māori Psychotherapy
}

Author: Margaret Poutu Morice

Supervisor: Dr Stephen Appel

Master of Psychotherapy Dissertation 2003 (AUT University)

"What lies behind us and what lies before us are small matters compared to what lies within us." This famous quote by Ralph Waldo Emerson (1803-1880) might be considered the psychotherapist's creed. In countless variations on this theme, psychotherapists around the world urge their clients to look inside themselves for answers, and clients, becoming aware of their inner world, claim a new-found sense of self-possession. The individual inner world is the world most familiar to us in our work as psychotherapists. But the idea that this world is its own separate and independent entity is utterly foreign to Mãori. Within the holistic world-view of Mãori, relationships are not limited or unique to the social milieu of human beings. Rather, they are understood as binding and connecting all of the worlds - physical, social, spiritual and cosmic. Each of these worlds has an internal representation and makes up parts of the individual psyche, which in turn is understood as a microcosm of the greater universe.

In the Māori world, what lies within us includes hau muri (the wind/breath behind) and hau mua (the wind/breath before). Our inner world is populated with nga tupuna, all those who have gone before. The future, unseen behind us and the past, visibly apparent before us are real and immediately present in this moment. As they lie within us, so equally we lie within them. We are inseparably and inescapably a manifestation of the greater whole, formed of the living body of Papatuanuku, Mother Earth, infused with the breath of Tane Mahuta, the God of humankind. The past secures the present, the present ensures the future. $\mathrm{We}$, in the present moment, are the connection, the indissoluble link between past and future. Traditional Māori concepts of relationship help to more precisely locate and describe the human person within this inclusive, holistic context. In this dissertation I will be defining and describing core relational concepts of traditional Māori society and seeking to establish their relevance both to the specific interpersonal practice called psychotherapy and to the broader field of human experience and human self-understanding. I have identified the following six relationships as central or core:

\author{
Manaakitanga - generosity, hospitality \\ Whanaungatanga - nurturing connection and belonging \\ Kaitiakitanga - guardianship, protection, caretaking \\ Kotahitanga - developing oneness, unity and integration \\ Rangatiratanga - self-determination, self-actualisation and leadership \\ Wairuatanga - spiritual awareness and the practice of spirituality
}

(Full dissertation available in hard copy form at AUT library, Special Collections, City Campus). 


\section{Cultural Identity in the Child Psychotherapy Environment: a Māori Perspective (2005)}

Author: Dr Alayne Hall

Supervisor: Dr Philip Culbertson

Master of Health Science 2005 (AUT University)

I have become increasingly curious about certain aspects that influence my practice. The combined influences of Māori and Pākehā contribute to my clinical practice and the interrelationships between others and myself. This dissertation aims to explore areas of wisdom that have educated and informed my clinical practice. Three distinct bodies of knowledge relating to temperament are presented as a catalyst for understanding which viewpoint is more likely to influence the therapist. The three perspectives include empirical studies, anthroposophy and the narratives of Maui. This dissertation examines the therapist choice of knowledge and how this knowledge informs her clinical practice. It examines the therapist countertransference and moments of conflict between differing sets of views. Furthermore, it acknowledges the challenges of living in two worlds and some of the implications for the therapists are discussed in brief. The dissertation closes with an argument that knowledge from the therapist's particular cultural setting cannot be disregarded. It also focuses on the importance of integrating this knowledge into clinical practice.

https://openrepository.aut.ac.nz/handle/10292/523

\section{Entering the Void: Exploring the Relationship Between the Experience of Colonisation and the Experience of Self for Indigenous Peoples of Aotearoa, and the Implications for Clinical Practice} Author: Wiremu Woodard

Supervisors: John O’Connor and Dr Andrew Duncan

Master of Psychotherapy Dissertation 2008 (AUT University)

This dissertation explores the relationship between the experience of colonisation and the experience of self for Indigenous Peoples of Aotearoa. The study suggests that an indigenous experience of self exists within a discursive relationship to colonisation processes. Using a modified systematic literature review located within a kaupapa Māori research framework, the study considers colonisation and the resultant disruption to an experience of indigenous 'selves'. The work examines the process of racialisation: the construction and resulting interiorisation of Indigenous Peoples as 'Other'. The review contends that this process has the effect of disrupting indigenous ontologies creating a divided and alienated experience of self for Indigenous Peoples. Within Aotearoa, the phenomenon of whakamā and mate Māori are hypothesised as the indigenous experience of this alienated and divided self. The study suggests that arguably all psychological issues for Indigenous Peoples of Aotearoa arise to some degree from these experiences. Implications for psychotherapy are considered. Psychotherapy and psychotherapists are challenged to re-evaluate both the underlying positivist conceptualisations of self, and ongoing processes of colonisation, in order that they may be more fully equipped to effectively work alongside Indigenous communities in Aotearoa. https://openrepository.aut.ac.nz/handle/10292/500 


\section{What are the Meanings of the Mātauranga Māori Concept of Mana and What Might This Concept Contribute to the Understanding and Practice of Psychodynamic Psychotherapy?}

Author: Joanne Reidy

Supervisor: John O’Connor

Master of Psychotherapy Dissertation 2014 (AUT University)

This dissertation explores the meanings of the Mātauranga Māori concept of mana and its relationship to psychodynamic psychotherapy. Using a critical review of the literature located within a Kaupapa Mãori research framework it undertakes an analysis of the meaning of mana. This meaning is recognised through the Māori concept of self interconnecting with spiritual power, authority, self image, and group connection, all of which involve merging the person with the environment. Associations between mana and the self in psychodynamic literature were critically reviewed, revealing similarities and divergences between these two world views. A psychodynamically informed mana enhancing psychotherapy is explored placing mana at the centre. The review contends that psychodynamic psychotherapy can become more culturally embracing through utilising mana enhancing values and extending relationships to a wider group context and the physical as well as interpersonal environment.

https://openrepository.aut.ac.nz/handle/10292/7863

\section{What is the Experience of Being Both Māori and Pākehā? Negotiating the Experience of the Hybrid Cultural Object?}

Author: Niki Grennell

Supervisor: Dr Keith Tudor

Master of Psychotherapy Dissertation 2014 (AUT University)

This dissertation addresses the question: "What is the experience of being both Mãori and Pākehā?" and has as its subtitle: "Negotiating the experience of the hybrid cultural object.” The methodologies used are Kaupapa Research Theory and phenomenology, with the principle method Heuristic Research Method. By 2051 Durie (2011) predicts that the Mãori ethnic population will rise to 22 percent of the total population of Aotearoa New Zealand. Each one of the 22 percent will not have only Māori ancestry. Each one of the 22 percent will have ancestry that is also other than indigenous to Aotearoa New Zealand. Currently Māori and Pākehā sit in binary positioning. This positioning has been essential for Māori who have needed strength of identity in order to counter the effects of colonisation. Pākehā have also benefited from maintaining Māori in the position of "other". It is common to name individuals as either Māori or Pākehā despite having ancestry that is both Māori and Pākehā. Those who have both Māori and Pākehā ancestry, a hybrid cultural identification, may become invisible in the current discourse, their experience denied. Phenotype becomes a marker of cultural identification from both external and internal perspectives. The researcher's personal experience of being both Māori and Pākehā, negotiating belonging and not belonging is used as a base from which to explore and expand knowledge of hybrid cultural experience.

https://openrepository.aut.ac.nz/handle/10292/7710 


\title{
An Indigenous Kaupapa Māori Approach: Mother's Experiences of Partner Violence and the Nurturing of Affectional Bonds with Tamariki
}

\author{
Author: Dr Alayne Hall
}

Supervisor: Dr Jane Koziol-McLain, Dr Lilly George

Doctor of Philosophy (PHD) Thesis 2015 (AUT University)

This thesis examines the important relationship dynamics between Māori mothers and their tamariki (children) when exposure to partner violence is experienced. The research is contextualised within a Kaupapa Māori methodology where Indigenous qualitative methods provide the foundations for theorising and researching. The study investigated twelve Māori mothers' experiences of partner violence, and the fostering of affectional bonds with their tamariki. The context for examining the interface between these two conditions included a Mana Wāhine approach and Pūrākau - a Māori narrative storytelling process where Māori mothers shared their experiences of partner violence and mothering. The pūrākau provided the main source of data from which Te-ata-tu Pūrākau emerged as a newly developed Indigenous analysis method.

Attachment theory provided useful insights concerning the nature in which affectional bonds develop between a young child and their primary caregiver, most often the mother. In this study whakapapa is fundamental to whānau, hapu and iwi, providing the cultural construct for understanding the way in which affectional bonds are developed and fostered in Māori kin based groups. Attachment theory is contrasted with Māori understandings that have a primary focus on whakapapa (genealogy) and Tühonotanga as two important concepts for understanding the nature of Māori relationships. The women who participated in this research study experienced different levels of disconnection from traditional Māori society where the break-down of traditional values contributed to their sense of mournfulness, mistrust, disillusionment, confusion, cynicism and a deep longing for healthy relationships. Some of the findings from this research are consistent with what we currently know about violence against women and children. Principally the pūrākau have revealed the need to develop healing pathways that validate core values that underpin a secure Māori identity, where Mana Wāhine and Mana Tangata provide the platform for positive relationship building.

https://openrepository.aut.ac.nz/handle/10292/9273

\section{“Our Māori Connection”:The Impact ofColonisation on OneSouthland Whānau}

Author: Verity Armstrong

Supervisor: Wiremu Woodard

Master of Psychotherapy Dissertation 2016 (AUT University)

This research includes an exploration of my whānau in Aotearoa reconnecting with their lost and regained whākapapa. The purpose of the study is an examination of the impact of colonisation on the cultural identity of members of a specific Māori whānau who have become disconnected from the tūrangawaewae of their ancestors, and their cultural roots. 
This work examines the history of colonisation in the area of Oraka-Aparima and the southern most part of Te Waipounamu. It employs the pūrākau method of research within kaupapa Māori research framework to gather stories from a Southland whānau. In keeping with the kauapapa of kaupapa Māori research, the pūrākau will be included in the body of the research, to ensure that the voices of the whannau members are heard. I wish to treat the pūrākau from my whānau with the deepest respect and for this reason, it is important that their voices and stories appear in the first part of this dissertation. Many themes have emerged from the pūrākau of my whānau. The themes explored include grief and loss through death and separation as well as assimilatory processes that resulted in the loss of such things as te reo and tikanga Māori within this whānau. This work also examines the healing and strengthening of identity that has occurred for whānau members through the process of reconnecting with the indigenous parts of themselves. Colonisation has both formed and devastated this Southland whānau in terms of cultural connection with their Màori identity. The assimilatory policies at the end of the eighteenth century and beginning of the nineteenth century prioritised European cultural practices over traditional tikanga Māori. In addition the lighter skin tone of many Ngāi Tahu Māori in the Southland area and a desire to conform to Pākehā society, led to a denial and disconnection with their Māoriness for many whānau members (Dacker, 1994; Anderson, 1998). In the later twentieth century my whānau have rediscovered their Māori ancestry and many members have taken steps towards reconnecting with their Māori identity. This process provides the clues towards greater integration and better outcomes for the individuals within whānau as well as whānau as a group. When the different parts of our identities can be celebrated and experienced in a non-hierachical way, it provides a way for those of mixed-descent within Aotearoa to honour their ancestors and themselves. The experience of colonisation informs the identities of all people of Aotearoa. Our society includes many peoples of mixed-descent who have unique as well as shared experiences in relation to the process of colonisation. By exploring the experiences of one whānau and some of its members in particular, it is hoped that the complex, rich and personal stories of encounter between Māori and Pākehā can add to the perspectives of colonial experience in Aotearoa.

https://openrepository.aut.ac.nz/handle/10292/10225

Ngā Tāpiritanga: In What Ways Are Indigenous Māori Perspectives on Attachment Similar to and Different From Western Psychoanalytic Perspectives on Attachment and What Are the Implications for the Practice of Psychotherapy in Aotearoa New Zealand? A Kaupapa Māori Critical Literature Review

Author: Anna Fleming

Supervisor: John O’Connor

Master of Psychotherapy Dissertation 2016 (AUT University)

Western attachment theory has tended to focus on the interpersonal attachments between people; only relatively recently have western perspectives begun to explore the quality of attachments outside of the interpersonal domain. By contrast, Indigenous Māori attachment 
perspectives have always included vital connections to cultural and collective concepts such as whānau, whenua, and wairua. This critical literature review utilises Kaupapa Māori Research Theory to explore similarities and differences between indigenous Māori and western concepts of attachment, while also examining the implications for psychotherapy in Aotearoa New Zealand.

https://openrepository.aut.ac.nz/handle/10292/10510

\section{The Greatest Story Ever Told, Using the Self as a Narrative.}

\section{Author: Hinewirangi Morgan}

Masters of Indigenous Knowledge Thesis (Te Wananga o Aotearoa).

Traditional narratives inform and guide cultural identity, determining the way a culture functions or operates. These narratives are continuously progressed and built upon by individuals, with each generation making their contribution. Although, in many instances, one has the power to fashion their narratives - such is not always the case. Life is full of contingent occurrences that lead to contingent outcomes; some positive, some negative. Furthermore, it is not always easy for one to look back and make sense of these occurrences and for this reason, so many narratives end abruptly, discouragingly, or dejectedly - the narrative captured within this exegesis is not one of them. This exegesis chronicles my life's journey and presents the contribution I have made to my narrative as I seek to understand myself, my practice, the knowledge I hold, and the incumbent responsibility to share the knowledge that I have acquired. The purpose of this study is to show the importance of narratives in understanding the past and constructing the present, and focuses on five dimensions of narratives (1) practical experience, (2) interpretation; (3) research; (4) contribution; and (5) transformation.

Full text of Thesis available from the Author.

\section{Conclusion}

The above is a sample of the diverse and invaluable research being undertaken by indigenous Māori researchers in the field of psychotherapy. The knowledge generated is a unique contribution within the Aotearoa New Zealand psychotherapy context. We are proud to provide this overview and hope it will provide an enriching resource for practitioners and researchers in the field of psychotherapy for many years to come, both within the Aotearoa New Zealand context and internationally. 


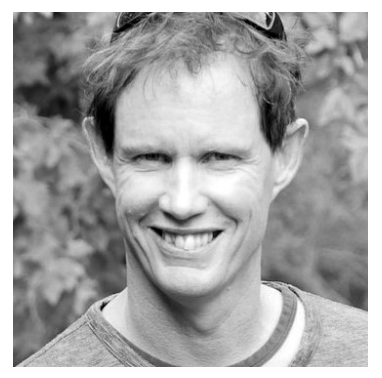

John O'Connor has worked as a counsellor and psychotherapist for over 30 years, and has a wide range of clinical experience, particularly in working with clients with severe trauma histories, in providing group psychotherapy, and in working crossculturally. He is a former Director of Youthline Counselling Service (Auckland) and the Human Development and Training Institute. He also formerly worked at Segar House (which is part of ADHB Mental Health Services) and was a founding member of the therapeutic team at Segar which developed a residential trea-tment service (currently operating as a day programme) for clients with personality disorder diagnoses. He has worked as a lecturer at the Auckland University of Technology within the Psychotherapy Discipline since 1999 and was formerly Programme Leader of the Master of Psychotherapy (adult programme) at AUT. He is co-editor of Ata: Journal of Psychotherapy Aotearoa New Zealand. John is an associate member of Waka Oranga. John also conducts a private practice in Mangere Bridge. John is currently a candidate in training as a Jungian Analyst with the Australia New Zealand Society of Jungian Analysts and is undertaking his $\mathrm{PhD}$ exploring the discourses underpinning bicultural clinical encounters in Aotearoa New Zealand. Contact details: johnnygj@xtra.co.nz. Phone 021-899-261.

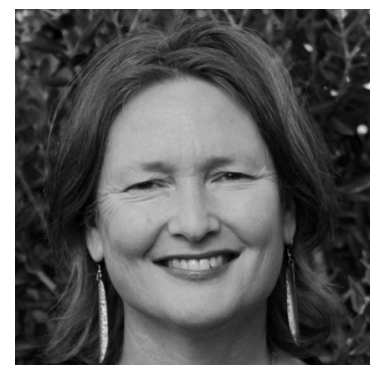

Verity Armstrong is a Kai Tahu woman from Aotearoa New Zealand. She also has strong connections to clans MacKintosh and Armstrong. While her whakapapa is from the bottom of Te Waipounamu in the stunning Oraka/Aparima area, she grew up in Tāmaki Makaurau. Verity worked as a social worker in the area of childhood trauma, and then trained as a psychotherapist through AUT. She worked for an organisation specialising in domestic and sexual violence, and is now in private practice, specialising in sexual trauma. She also has an interest in sex positivism, relationships and love.Verity joined the runanga of Waka Oranga after experiencing their support and wisdom throughout her training and beginning years as a psychotherapist. Verity is married to her partner of many years, and has three tamariki. Her experience of mothering and being in relationship, and all of the learning this involves bring her a wealth of experiences, feelings and growth. Contact details: verityarmstrong@gmail.com. 